\title{
Climate Change Dynamics and Imperatives for Food Security in Nigeria
}

\author{
Olumide D. Onafeso, Cornelius O. Akanni and Bamidele A. Badejo
}

Received: 3001 2015 / Accepted: 20052015 / Published online: 15022016

(C) 2015 Faculty of Geography UGM and The Indonesian Geographers Association

\begin{abstract}
Decadal variability in African rainfall is projected from General Circulation Models (GCMs) to continue under elevated greenhouse gas scenarios. Effects on rain intensity, spatio-temporal variability of growing seasons, flooding, drought, and land-use change impose feedbacks at regional-local scales. Yet, empirical knowledge of associated impacts on crop yield is limited; thus, we examined the imperatives for food security in Nigeria. Bivariate correlation and multiple regression suggests impending drought in the northern region where livestock farming is predominant. Relative contributions of climate independent variables in determining crop yield by backward selection procedures with stepwise approach indexed the impacts of annual climate variability by a parameter computed as annual yield minus mean annual yield divided by the standard deviation. Results show Z-distribution approximately 5 to +5 , when $<3$ or $>3$ indicate impacts significant at $95 \%$ confidence levels. In conclusion, we established the interwoven relationship between climatic change and food security.
\end{abstract}

Keywords: Climate change, Food security, Africa

\begin{abstract}
Abstrak Variabilitas curah hujan dekade Afrika diproyeksikan oleh Sirkulasi Umum Model (GCMS) untuk terus berada di bawah skenario gas rumah kaca yang tinggi. Efek pada intensitas hujan, variabilitas spasial-temporal musim tumbuh, banjir, kekeringan, dan perubahan penggunaan lahan memaksakan masukan pada skala regional-lokal. Namun, pengetahuan empiris dampak yang terkait pada hasil panen terbatas; dengan demikian, dilakukan penelitian untuk ketahanan pangan di Nigeria. Korelasi bivariat dan regresi ganda menunjukkan kekeringan yang akan datang di wilayah utara di mana peternakan dominan. Kontribusi relatif dari variabel independen iklim dalam menentukan hasil panen oleh prosedur seleksi mundur dengan pendekatan bertahap diindeks dampak variabilitas iklim tahunan oleh parameter dihitung sebagai hasil tahunan dikurangi hasil tahunan rata-rata dibagi dengan standar deviasi. Hasil penelitian menunjukkan Z-distribusi sekitar 5 sampai +5 , ketika $<3$ atau $>3$ menunjukkan dampak yang signifikan pada tingkat kepercayaan 95\%. Kesimpulannya, terjadi hubungan terjalin antara perubahan iklim dan ketahanan pangan.
\end{abstract}

Kata kunci: Perubahan iklim, Keamanan pangan, Afrika

\section{Introduction}

It has been suggested that by 2050, air temperatures above $30^{\circ} \mathrm{C}$ will be common in East and Southern Africa and that shorter growing seasons in East and West Africa may make cropping an even more risky enterprise (Ericksen et al., 2011). These impacts of climate change and variability will take a visible toll on the most vulnerable population; by 2050 , as calorie availability declines, child malnutrition is projected to increase by 20 per cent over a no-climate-change world. Africa has historically been subject to high air temperatures, droughts, floods and environmental degradation. Africa has also been reported to experience the worst effects of climate change and is the most vulnerable continent. Flooding and droughts are

Olumide D. Onafeso, Cornelius O. Akanni and Bamidele A. Badejo Department of Geography and Regional Planning, Olabisi Onabanjo University, Ago-Iwoye, Nigeria

Email: olumide.onafeso@oouagoiwoye.edu.ng now common across Africa. The importance of climateresilient food systems cannot be overstated - many of the countries with the greatest number of poor and hungry people are also those most vulnerable to climate change and variability (Bello, et al. 2004; Ahmed et al., 2009). Vulnerability is dynamic, locally specific and manifested along sector, community and poverty lines (Acosta-Michlik et al., 2008; Hertel and Rosch, 2010).

Food security has been described as an important aspect in any consideration of wealth and economic sustainability of a nation. It is generally defined as access by all people at all times to enough food for an active and healthy life. Important aspects to be considered in food security issues include the availability of food stuff, the quality of the diet, the stability of supplies over time and space and access to food produced (Honfoga and van den Boom, 2003). The World Health Organisation recommends an intake of between 2500 - $3400 \mathrm{Kcal}$ 
of energy per person per day. It is recommended that an individual should consume between $65-86 \mathrm{~g}$ crude protein per day out of which $35 \mathrm{~g}$ (or $40 \%$ ) must be animal protein. Food insecurity remains a global threat and human tragedy. It is by any measure a miserable picture, which does not reflect well on the efforts that have gone into the hunger alleviation programmes on which enormous sums of public funds have been lavished. The persistence of hunger in the developing world means that ensuring adequate and nutritious food for the population will remain the principal challenge facing policy makers in many developing countries in the years to come. Food insecurity is a particularly serious issue in many low income countries. For instance, sub-Saharan Africa and South Asia stand out as the two developing-country regions where the prevalence of human malnutrition remains high. The largest absolute numbers of undernourished people are in Asia, while the largest proportion of the population that is undernourished is in Africa, south of the Sahara In terms of proportionality, this was estimated at 34 percent in Africa and 23 percent in South Asia.

FAO, WFP and IFAD (2012) recognized the potential of economic growth to accelerate reductions in hunger, poverty and malnutrition, and also drew attention to the association of globalization and economic growth with the trend towards overnutrition, even in low-income countries. The societal transformations that have been observed in the process of economic growth, modernization and urbanization, have led a growing number of people to adopt lifestyles and diets that are conducive to overweight and related non-communicable diseases. The negative implications for public health systems are already significant in many countries, together with post-harvest losses, excessive consumption and waste draw on scarce resources that could be used to improve the nutrition of the poor and hungry while reducing the food system's environmental footprint. However, very few studies have attempted an analysis of the possible impact global warming and climate change would have on food security, especially in Africa.

Food insecurity and hunger are forerunners to nutritional, health, human and economic development problems. They connote deprivation of basic necessities of life. As such, food security has been considered a universal indicator of households' and individuals' personal well being. The consequences of hunger and malnutrition are already adversely affecting the livelihood and well being of a massive number of people and inhibiting the development of many poor countries. Malnutrition affects one out of every three preschool-age children living in developing countries. This disturbing, yet preventable state of affairs causes untold suffering and presents a major obstacle to the development process. It is associated with more than half of all child deaths worldwide. It is therefore the bane of a major waste of resources and loss of productivity which are common occurrences in developing countries. This is because children who are malnourished are less physically and intellectually productive as adults. As such, malnutrition is a violation of the child's human rights (Smith et. al,, 2003). Although, the root problem of inadequate access to food is poverty, the challenge can be significantly exacerbated by climate change and global warming. This is in the sense of the failure of the economic system to generate sufficient income and distribute it broadly enough to meet households' basic needs. The problem can be addressed by either giving food directly to the poor (non-market distribution of aid); increasing their incomes so that they have greater entitlement to food through the market (given existing marketing costs); and/or reducing the costs of food delivered through markets by fostering technical and institutional innovations in farm-level production and the marketing system.

This paper examines the imperatives for food security in the dynamics of climate change and global warming at the local Nigerian scale. It also considers the causes of vulnerability to climate variability in terms of exposure, impacts and adaptive capacity and how it exacerbates household food insecurity. This aims to help inform policy or interventions that support rural communities to cope and adapt to current and future effects of climate variability. In cropping areas critical to national and regional food security where farmers are already struggling under current climate change and variability, future hydrological conditions are likely to be more extreme than those in the past, and mean temperatures are projected to exceed historical observations in the next 10-15 years (Mcintyre et al., 2011; Battisti and Naylor, 2009).

\section{The Methods}

The parameters used in this study to assess food security includes food production index, livestock production index, cereal yield, crop production index, population density Annual Averaged Temperature and Annual Averaged Total Rainfall. Following the recommendation of experts gathered in the Committee on World Food Security (CFS) Round Table on hunger measurement, hosted at FAO headquarters in September 2011, an initial set of indicators aiming to capture various aspects of food insecurity was designed. The choice of the indicators has been informed by expert judgment and the availability of data with sufficient coverage to enable comparisons across regions and over time. Many of these indicators are produced and published elsewhere by FAO and other international organizations. They were employed in this study with the aim of defining a wide food security information system. Indicators were classified along the four dimension of food security, that is, availability, access, utilization and stability. To further facilitate their interpretation they are also classified as indicators of determinants and outcomes of food insecurity. 
Determinants, which can be either static or dynamic, refer to structural conditions that worsen food insecurity in absence of adequate policy interventions, including emergency assistance. Outcome indicators capture results in terms of inadequate food consumption or anthropometric failures.

According to the Food and Agriculture Organisation, food production index covers food crops that are considered edible and that contains nutrients whereas livestock production index includes meat and milk from all sources, dairy products such as cheese, and eggs, honey, raw silk, wool, and hides and skins. Similarly, cereal yield measured as kilogram per hectare of harvested land includes wheat, rice, barley, oats, rye, millet, sorghum, buckwheat, and mixed grains. Production data on cereal relate to crops harvested for dry grain only. Cereal crops harvested for hay or harvested green for food, feed, or silage and those used for grazing are excluded. The FAO allocates production data to the calendar year in which the bulk of the harvest took place. Most of crops harvested near the end of a year were used in the following year. Crop production index shows agricultural production for each year relative to the base period 2004-2006. It includes all crops except fodder crops. Regional and income group aggregates for the FAO's production indexes are calculated from underlying values in international dollars, normalized to the base period. Population density was taken as midyear population divided by land area in square kilometres. Population is based on the de facto definition of population, which counts all residents regardless of legal status or citizenship, except for refugees not permanently settled in the country of asylum, who are generally considered part of the population of their country of origin. Land area is a country's total area, excluding area under inland water bodies (i.e. major rivers and lakes), national claims to continental shelf, and exclusive economic zones.

Whereas, food production index, livestock production index, cereal yield, crop production index, population density (all drawn from the world bank data portal) as well as annual averaged temperature and annual averaged total rainfall (obtained from the Nigerian Meteorological Agency, and averaged for Ibadan, Calabar, Enugu, Jos, Maiduguri and Kaduna) were analysed for a fifty year period ranging between 1961 and 2013, all other parameters (acquired from the FAO data portal) were analysed for a twenty year period ranging between 1990 and 2013 for paucity of data. Missing data were treated as mean of the series in each case.

Analyses of sensitivity to inter-annual and intraannual climate variability were done by using bivariate Persons correlation and multiple regression methods. Estimation of the relative contributions of each climate independent variable was employed in determining the variability of food security parameters using the backward selection procedures for the regression.
Stepwise approach was adopted for the intra-annual study indexing the impacts of annual climate variability by a parameter computed as annual yield minus mean annual yield divided by the standard deviation. The results produced a Z-distribution array with values varying from approximately -5 to approximately +5 . Values $<-3$ or $>3$ indicate impacts that are significant at 95 percent confidence levels.

\section{Result and Discussion}

Agriculture is the mainstay of Nigeria's economy, employing approximately two-thirds of the country's total labour force and contributing 40 per cent to the GDP. Nigeria is the world's largest producer of cassava, yam and cowpea; yet it is a food-deficient nation depending on imports of grains, livestock products, and fish (IFAD, 2012). Of an estimated 71 million hectares of cultivable land, only half is currently used for farming; there is similar potential for an expansion of irrigation, which now only covers 7 per cent of irrigable land. Most of the rural population farms on a subsistence scale, using small plots and depending on seasonal rainfall. Pressure from growing populations is also impacting already diminished resources, further threatening food production. Over-farmed land, deforestation, and overgrazing are severe in many parts of the country. Drought has become common in the north, while erosion and flooding is a major problem in the south. Even though Nigeria is not facing a major hunger crisis at the moment, the dynamics of the nation's food supply system requires adequate assessment to forestall acute and severe food deficit. Many analysts have noted that Nigeria's current food security is by no means sustainable noting that a situation where the country spends about one trillion naira annually on food importation is not sustainable. According to a former Minister of Agriculture, Nigeria spends N635 billion on importations of wheat, N356 billion on importations of rice, N217 billion on sugar importations, and N97 billion on importations of fish as expressed in a Thisday Newspaper article of 10 Sep 2013.

Over the past five decades, the value for the food production index in Nigeria has fluctuated between 104.69 in 2006 and 22.51 in 1961, while the value for livestock production index has fluctuated between 122.97 in 2011 and 20.95 in 1962 . The value for Cereal yield (kg per hectare) in Nigeria was 1330.90 as of 2011. As shown in Figure 1, over the past 50 years, this indicator reached a maximum value of 1655.50 in 1981 and a minimum value of 607.80 in 1966. Cereal yield in the country showed a linear trend which indicates an annual growth of about $16.619 \mathrm{~kg}$ per hectare annually. The value for crop production in Nigeria has fluctuated from 21.99 in 1961 to a peak of 105.31 in 2006. The value for population density in Nigeria has continued to rise systematically from 51.51 since the year 1961 . The value for the depth of food deficit (kilocalories per person per day) in Nigeria was 50.00 as of 2012 . 


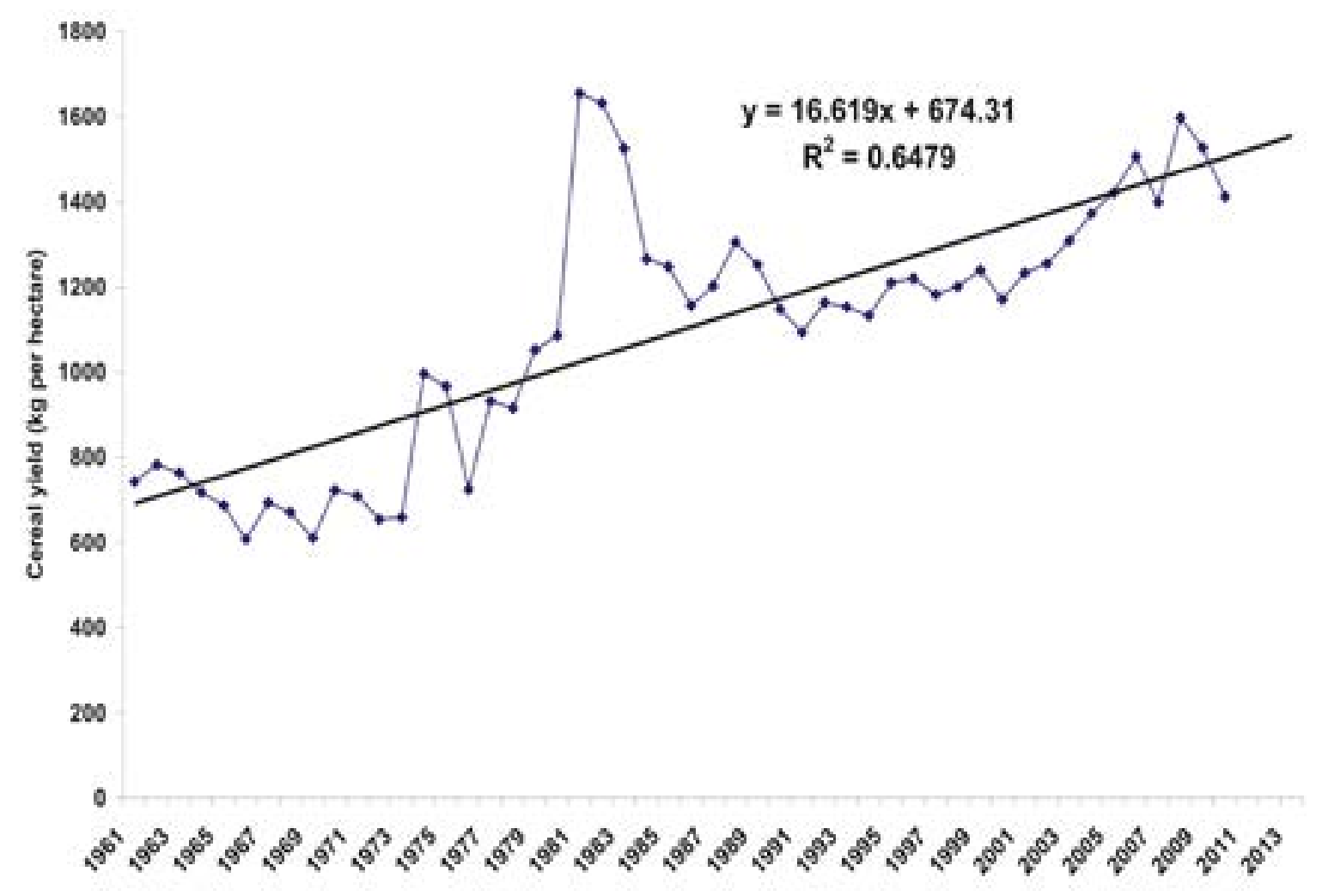

Figure 1. Cereal yield in Nigeria over the years

Over the past 20 years, food deficit in Nigeria reached a maximum value of 120.00 in 1992 and a minimum value of 39.00 in 2006.

Rainfall is the key climatic variable with marked alternation of wet and dry seasons in most areas. Given the climatological cycle and the size of the country, there is a considerable range in total annual rainfall across Nigeria, both from south to north and, in some regions, from east to west. The highest total precipitation is generally in the southeast, along the coast where mean annual rainfall is more than 4,000 millimetres. Most of the rest of the southeast receives between 2,000 and 3,000 millimetres of rain annually, and the southwest (lying farther north) receives lower total rainfall, generally between 1,250 and 2,500 millimetres (Onafeso and Olusola, 2014). The average rainfall pattern computed for this study is equally highly variable showing significant wet and dry spells of inter annual variability which reflects the Sahelian fluctuations especially the pre 1970 wet period and the long drought that followed. As shown in Figure 2, the great Sahelian drought (Biasutti and Giannini, 2006; Cook, 2008) which caused famine and dislocation on a massive scale from 1968 to 1974 and again in the early and mid-1980s in many West African countries is reflected in the rainfall variability over Nigeria.

The impact of rainfall variability on food security is expected to be considerable as indicated in the results of bivariate correlations employing Pearson's method as presented in Table 1. While the correlation matrix indicates strong positive significant correlations of 0.947 , 0.961, 0.989 and 0.779 between Annual Averaged Total Rainfall and Crop production index $(2004-2006=100)$, Food production index $(2004-2006=100)$, Livestock production index $(2004-2006=100)$, and Cereal yield (kg per hectare) respectively. Since majority of the livestock produced in the country is from the northern regions, it is most plausible to conclude that the effects of the rainfall variability attenuated by the Sahelian desiccations is responsible for the near synchroneous response indicated in the 0.989 correlation between Annual Averaged Total Rainfall and Livestock production index in Nigeria within the five decades between 1961 and 2013. Similarly, the Annual Averaged Temperature is also positively correlated to livestock production index and cereal yield, although with less strong but significant [at the 0.01 level (2-tailed)] values of 0.379 and 0.353 respectively.

Several studies have predicted possible impacts of future climate change using General Circulation Models. Onafeso (2012) compared three GCMs - CGCM3, CSIROMk3 and HadCM3 - with observed annual rainfall (1961-1990) employing paired sample t-test and Nash-Sutcliffe efficiency test to validate the model and concluded that while CGCM3 underestimated wet season rainfall with $10 \%$ efficiency across Nigeria, 
CSIROMk3 overestimated wet season rainfall in the southern parts of Nigeria, whereas, HadCM3 simulated rainfall all over Nigeria with $85 \%$ efficiency, recommending that HadCM3 is most appropriate for climate change projections in the region. The study predicted increased annual rainfalls in the southern parts of Nigeria which would result in surplus runoff and flooding from the year 2040. However, the study further projected a decline of $15.0 \pm 0.5 \%$ in annual rainfall from the 1961-1990 mean values for 20402060 and a further decline of $41.3 \pm 0.1 \%$ for 2070 2099 especially in the northern regions of Nigeria (i.e. upstream Lokoja along the River Niger). This projected decline in annual rainfall and consequent runoff is believed to cause possible severe drought as suggested by other studies (Ekpoh and Nsa, 2011).

The implication of these plausible water stress in the northern parts of the country would impose untold consequences on several agricultural ventures most especially livestock production (Thornton et al., 2009). Beyond high prices of staple food items in Nigeria due to inflation and economic instability, drought is likely to pose serious threat in the future. Another problem according to the Ministry of Agriculture and Water Resources, responsible for the food crisis in Nigeria is not unconnected with the fact that "Nigeria's agriculture is mainly rain-fed and she has not taken full advantage of its irrigation potential estimated between two and 2.5 million hectares" (Ojo and Adebayo, 2012). The area under irrigation is officially estimated at about 220,000 hectares or less than one per cent of the total areas under crops suggesting that the contribution of irrigated agriculture to crop production is relatively very small.

In contrast, while drought may pose major problems for the affordability and availability of food items, excessive rain has also proved to have contributed significantly to the current hike in food prices in the country. Statistics from Gombe State alone as compiled by Gombe State Emergency Management Agency (GSEMA) show that about 999 farmlands in the state were affected by floods which destroyed yams, maize, vegetable, sugarcane and cassava farms in 2007. In the year 2012, over 5,000 farmlands was destroyed by flooding across the country, more than 800 hectares of yam and plantain farms were destroyed by flood in three communities in Oshimili South and Ndokwa East Local Government of Delta State, over 350 hectares of cassava farmland were destroyed in Edo State and rice farms were also destroyed in Kano State. Similarly, several reports of flooding incidences were made in the year 2013 including the 300 houses and farmlands

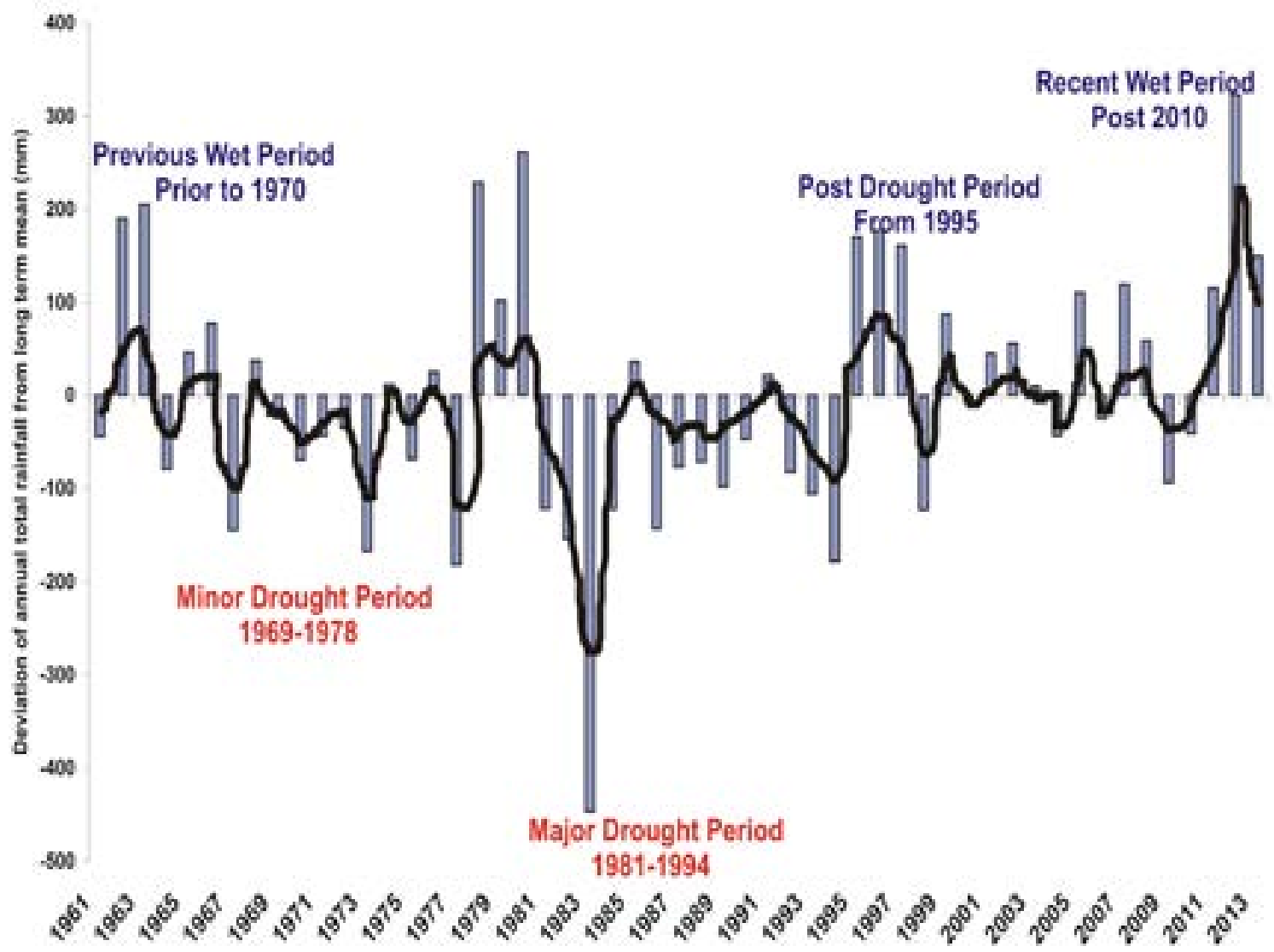

Figure 2. Rainfall variability over Nigeria 1961 - 2013 
Table 1. Bivariate Correlation of Climate and Food Security Indicators

\begin{tabular}{|c|c|c|c|c|c|c|c|}
\hline & $\begin{array}{c}\text { Annual } \\
\text { Averaged } \\
\text { Total Rain- } \\
\text { fall }\end{array}$ & $\begin{array}{l}\text { Annual } \\
\text { Averaged } \\
\text { Tempera- } \\
\text { ture }\end{array}$ & $\begin{array}{l}\text { Population } \\
\text { density } \\
\text { (people per } \\
\text { sq. km of } \\
\text { land area) }\end{array}$ & $\begin{array}{c}\text { Crop } \\
\text { produc- } \\
\text { tion index } \\
(2004-2006 \\
=100)\end{array}$ & $\begin{array}{c}\text { Food } \\
\text { produc- } \\
\text { tion index } \\
(2004-2006 \\
=100)\end{array}$ & $\begin{array}{l}\text { Livestock } \\
\text { produc- } \\
\text { tion index } \\
(2004-2006 \\
=100)\end{array}$ & $\begin{array}{c}\text { Cereal yield } \\
\text { (kg per } \\
\text { hectare) }\end{array}$ \\
\hline $\begin{array}{l}\text { Annual } \\
\text { Averaged } \\
\text { Total Rain- } \\
\text { fall }\end{array}$ & 1 & -0.139 & 0.103 & $0.947\left(^{* *}\right)$ & $0.961\left(^{\star \star}\right)$ & $\left.0.9899^{\star *}\right)$ & $\left.0.7799^{(* *}\right)$ \\
\hline $\begin{array}{l}\text { Annual } \\
\text { Averaged } \\
\text { Tempera- } \\
\text { ture }\end{array}$ & -0.139 & 1 & $0.376\left(^{* *}\right)$ & 0.240 & 0.259 & $0.379\left(^{* *}\right)$ & $0.353\left(^{*}\right)$ \\
\hline $\begin{array}{l}\text { Population } \\
\text { density } \\
\text { (people per } \\
\text { sq. km of } \\
\text { land area) }\end{array}$ & 0.103 & $0.376\left(^{* *}\right)$ & 1 & 0.159 & 0.147 & 0.043 & -0.157 \\
\hline $\begin{array}{l}\text { Crop } \\
\text { produc- } \\
\text { tion index } \\
(2004-2006 \\
=100)\end{array}$ & $0.947\left(^{* *}\right)$ & 0.240 & 0.159 & 1 & $\left.0.9999^{* *}\right)$ & $0.911\left(^{* *}\right)$ & $\left.0.619{ }^{* *}\right)$ \\
\hline $\begin{array}{l}\text { Food } \\
\text { produc- } \\
\text { tion index } \\
(2004-2006 \\
=100)\end{array}$ & $0.961\left(^{* *}\right)$ & 0.259 & 0.147 & $0.999\left(^{* *}\right)$ & 1 & $\left.0.9311^{* *}\right)$ & $\left.0.649{ }^{* *}\right)$ \\
\hline $\begin{array}{l}\text { Livestock } \\
\text { produc- } \\
\text { tion index } \\
(2004-2006 \\
=100)\end{array}$ & $\left.0.9899^{* *}\right)$ & $0.379\left(^{* *}\right)$ & 0.043 & $0.911\left(^{* *}\right)$ & $\left.0.9311^{\star *}\right)$ & 1 & $0.819\left(^{\star *}\right)$ \\
\hline $\begin{array}{l}\text { Cereal yield } \\
\text { (kg per } \\
\text { hectare) }\end{array}$ & $0.779\left(^{* *}\right)$ & $0.353\left(^{*}\right)$ & -0.157 & $0.619\left(^{* *}\right)$ & $\left.0.6499^{* *}\right)$ & $0.819\left(^{* *}\right)$ & 1 \\
\hline
\end{tabular}

in Kaduna, and the recent July, 2014 flood in Kutufare village of Gudu Local Government Area in Sokoto State where about 65 farmlands and farm produce worth millions of naira were washes off by the flood due to the over flow of the Kalmalo River.

Whereas, climatic conditions favour the currently rising food prices, the deficiencies in the delivery of farm inputs also come to the fore as a major challenge to farmers. Another factor is the low usage of fertilizers, occasioned by using the poor level of availability resulting in low crop yield. The Ministry of Agriculture and Water Resources has disclosed that current use of fertilizer is about 1,000,000 metric tones per annum, while the projected demand estimate is 3.7 million metric tones. While the "average worldwide rate is $93 \mathrm{~kg}$ per hectare of NPK, the rate for Nigeria is around $13 \mathrm{~kg}$ per hectare" (Ojo and Adebayo, 2012).

An estimation of the relative contributions of each climate independent variable, that is, the Annual Averaged Total Rainfall and the Annual Averaged Temperature in determining the variability of crop yield taking crop production index, livestock production index and cereal yield as dependent variables using the backward selection procedures for the regression in the case of inter-annual variability showed significant difference. For the sake of efficiency, the population 
Table 2. Stepwise Regression Model of Climate and Food Security Indicators

\begin{tabular}{|c|c|c|c|c|c|c|c|c|c|c|}
\hline \multirow[t]{2}{*}{ Model } & \multirow{2}{*}{$\begin{array}{c}\mathrm{R} \\
\mathrm{R} 2 \\
\text { Change }\end{array}$} & \multirow{2}{*}{$\begin{array}{c}\text { R2 } \\
\text { F } \\
\text { Change }\end{array}$} & \multirow{2}{*}{$\begin{array}{c}\begin{array}{c}\text { Adjust- } \\
\text { ed R2 }\end{array} \\
\text { df1 }\end{array}$} & \multirow{2}{*}{$\begin{array}{c}\text { Std. Error } \\
\text { of the Esti- } \\
\text { mate } \\
\text { df } 2\end{array}$} & \multicolumn{5}{|c|}{ Change Statistics } & \multirow{2}{*}{$\begin{array}{c}\text { Durbin- } \\
\text { Watson } \\
\text { Sig. F } \\
\text { Change }\end{array}$} \\
\hline & & & & & $\begin{array}{c}\text { Sig. F } \\
\text { Change }\end{array}$ & $\begin{array}{l}\text { R Square } \\
\text { Change }\end{array}$ & $\begin{array}{c}\mathrm{F} \\
\text { Change }\end{array}$ & df1 & $\mathrm{df} 2$ & \\
\hline $\begin{array}{l}\text { Crop } \\
\text { produc- } \\
\text { tion index } \\
(2004- \\
2006= \\
100)\end{array}$ & .947 & .897 & .894 & 398.25098 & .897 & 416.064 & 1 & 48 & .000 & .204 \\
\hline $\begin{array}{l}\text { Livestock } \\
\text { produc- } \\
\text { tion index } \\
(2004- \\
2006= \\
100)\end{array}$ & .989 & .978 & .977 & 191.09816 & .835 & 1810.355 & 1 & 47 & .000 & .573 \\
\hline $\begin{array}{l}\text { Cereal } \\
\text { yield (kg } \\
\text { per hect- } \\
\text { are) }\end{array}$ & .783 & .614 & .597 & 8502.77410 & .490 & 59.589 & 1 & 47 & .000 & .508 \\
\hline $\begin{array}{l}\text { a Predictors } \\
\text { (people per s } \\
\text { b Dependen } \\
\text { c Dependen } \\
\text { d Dependen } \\
\text { e Weighted }\end{array}$ & $\begin{array}{l}\text { Constan } \\
\text {. km of la } \\
\text { Variable: } \\
\text { Variable: } \\
\text { Variable: } \\
\text { east Squa }\end{array}$ & $\begin{array}{l}\text { ), Annual } \\
\text { nd area) } \\
\text { Crop proc } \\
\text { Livestock } \\
\text { Cereal yie } \\
\text { es Regres }\end{array}$ & $\begin{array}{l}\text { Averaged } \\
\text { luction in } \\
\text { productio } \\
\text { ld (kg per } \\
\text { ion - Wei }\end{array}$ & $\begin{array}{l}\text { Total Rainfall, } \\
\text { ex (2004-2006 } \\
\text { index ( } 2004- \\
\text { hectare) } \\
\text { hted by Year }\end{array}$ & $\begin{array}{l}\text { Annual A } \\
=100) \\
2006=10\end{array}$ & veraged $\mathrm{T}$ & peratur & & tion & nsity \\
\hline
\end{tabular}

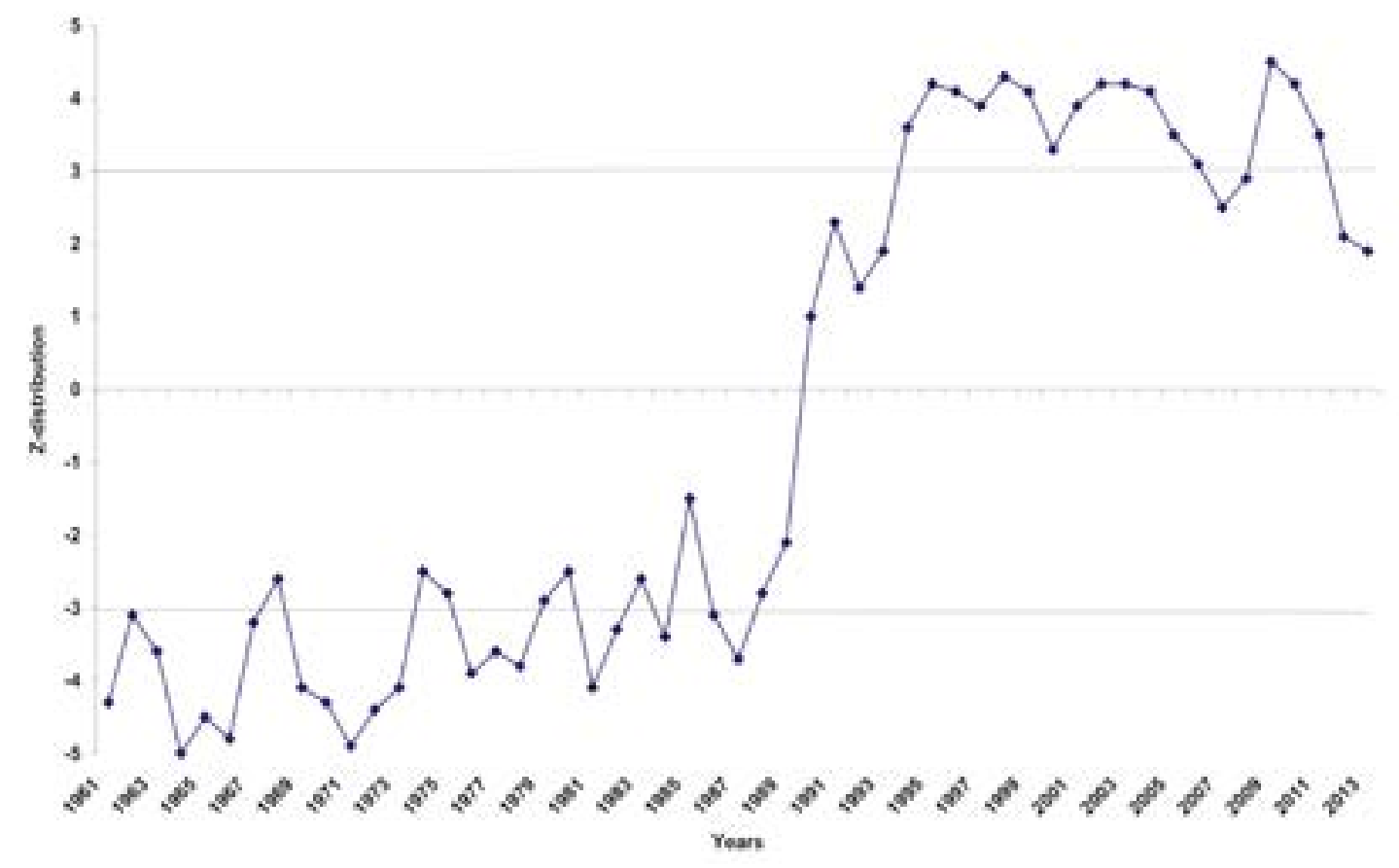

Figure 3. Z-distribution array of the impact of climatic variability on food security 
density was also factored into the equation as a predictor, as such the stepwise approach adopted for the intra-annual study indexing the impacts of annual climate variability by a parameter computed as annual yield minus mean annual yield divided by the standard deviation. Table 2 indicates the model parameters which very strong significant $\mathrm{F}$ changes in the Dubin-Watson statistics especially a 0.508 value for cereal yield. This presupposes that the effect of climatic variables on the selected food security indices is very strong.

The very high $\mathrm{R} 2$ change values also suggest the reliability of the model. The results produced from the parameter computed as annual yield minus mean annual yield divided by the standard deviation is shown in Figure 3, where the Z-distribution array fall within values varying from approximately -5 to approximately +5 . Consequently, values ranging $<-3$ or $>3$ indicate impacts that are significant at 95 percent confidence levels. These impacts are thus more prevalent between 1983 and 1995 and from around 2010 till date with a currently declining trend showing significant impact due largely to flooding of farmland areas and drought in the south and the north respectively.

\section{Conclusion}

Nigeria is a food-deficit country that on occasions has been dangerously dependent on food imports for the welfare of its people. Its agricultural sector has ceased to be an important contributor to foreign exchange earnings; even its contribution to employment has declined. This situation had not always been so and in fact, Nigeria used to be a major exporter of food crops until the discovery of crude oil in the late 1960s/early 1970s which led to a massive exodus of youths from farming into the cities in search of white collar jobs.

The prevailing low productivity in agriculture gives causes for much concern. Looking inward to increased agricultural production remains an absolute necessity for ensuring satisfactory food supply to the citizenry. To this extent, farmers, policy makers, government and non-government agencies concerned with agricultural development must respond positively to the considerable challenges of achieving self -sufficiency in food production and providing agricultural raw materials for industrial economy. The realization that the resource-poor farmers form the core of the Nigerian agriculture brings this group to the centre stage of efforts to move the agricultural sector forward.

The attendant effects of climate change and global warming are likely to increase the threat to food security and intensify the already tense situation of malnutrition and food insecurity in Nigeria. This is due to the plausible inhibition of agricultural productivity as a result of alterations to the growing season, onset of rainfall and climatic variability all of which are likely to adversely affect food production and crop yield. Moreso, little is yet know of how the impacts of drought and flooding would play in the scenario of both subsistence and mechanized farming in the country. Further studies are required to present empirical pictures of the impact of climate change and global warming on food security in Nigeria, to heave on the knowledge gaps presented by the present study.

\section{References}

Acosta-Michlik, L., Kelkar, U., Sharma, U., 2008, 'A critical overview: local evidence on vulnerabilities and adaptations to global environmental change in developing countries', Global Environmental Change 18, 539-542.

Ahmed, S.A., Diffenbaugh, N.S., Hertel, T.W., 2009, 'Climate volatility deepens poverty vulnerability in developing countries', Environmental Research Letters 4, 1-8. doi:10.1088/1748-9326/4/3/034004.

Battisti, D.S., Naylor, R.L., 2009, 'Historical warnings of future food insecurity with unprecedented seasonal heat', Science 323, 240-244.

Bello, N.J., Ufoegbune, G.C., Akanni, C.O. 2004, Climatic Classification Approach to Agricultural Land Use Planning in Ogun-Oshun River Basin Area Nigeria. Journal of Meteorological Society 4 (1): 50-62.

Biasutti, M. and Giannini, A., 2006. Robust Sahel drying in response to late 20th century forcings. Geophys. Re. Lett. 11, L11706. doi:10.1029/2006G1026067.

Burke, M.B., Lobell, D.B., Guarino, L., 2009, 'Shifts in African crop climates by 2050, and the implications for crop improvement and genetic resources conservation, Global Environmental Change 19, 317-325.

Cook, K.H., 2008, Climate science: The mysteries of Sahel droughts. Nature Geoscience 1, 647-648.

Ekpoh, I.J. and Nsa, E. 2011, Extreme Climatic Variability in North-western Nigeria: An Analysis of Rainfall Trends and Patterns. Journal of Geography and Geology. 3 (1): 51-62.

Ericksen, P., Thornton, P., Notenbaert, A., Cramer, L., Jones, P., Herrero, M., 2011, Mapping Hotspots of Climate Change and Food Insecurity in the Global Tropics, CCAFS Report No. 5, CGIAR Research Program on Climate Change, Agriculture and Food Security (CCAFS). Copenhagen, Denmark [available at www.ccafs.cgiar.org].

FAO, WFP and IFAD. 2012, The State of Food Insecurity in the World 2012. Economic growth is necessary but not sufficient to accelerate reduction of hunger and malnutrition. Rome, FAO.

Hertel, T.W., Rosch, S.D., 2010, Climate Change, Agriculture and Poverty, Policy Research Working Paper 5468, TheWorld Bank, Development Research Group, Agriculture and Rural Development Team.

Honfoga, B.G. and G.J. M. van den Boom 2003, "FoodConsumption Patterns in Central West Africa, 1961 to 2000, and Challenges to Combating Malnutrition" Food and Nutrition Bulletin, 
24(2):167-182, The United Nations University.

Mcintyre, B., Kim, Y., Fruci, J. and Rosenthal, E. (2011) The bestlaid plans: Climate change and food security, Climate and Development, 3:4, 281-284, DOI: 10.1080/17565529.2011.617564

Ojo, E.O. and Adebayo, P.F. 2012, Food Security in Nigeria: An Overview. European Journal of Sustainable Development 1 (2): 199-222. ISSN: 2239-5938

Onafeso,O.D.andOlusola O.A.2014,Evapotranspiration Modelling and Ecogeomorphological Classification of Lanscapes. National Colloquium on Frontiers in Environmental Research and Sustainable Environment in the 21st Century. University of Ibadan.
Onafeso, O.D. 2012, Analysis of Changes in Rainfall Pattern and Runoff Predictions for the Lower River Niger, Nigeria. An unpublished PhD. Thesis in the Department of Geography submitted to the Faculty of Science, University of Ibadan. 226pp.

Smith, L.C; U. Ramakrishnan; A. Ndiaye; L. Haddad and R. Martorell (2003), The Importance of Women's Status for Child Nutrition in Developing Countries, Research Report Abstract 131, IFPRI

Thornton, P.K., van de Steeg, J., Notenbaert, A., Herrero, M., 2009, 'The impacts of climate change on livestock and livestock systems in developing countries: a review of what we know and we need to know', Agricultural Systems 101, 113-127. 